\title{
Reconstruction Regulation of Zonation Expansion of Notary Position in Indonesia Based on Justice Value
}

\author{
Erwin Riduan ${ }^{1 *}$, Lazarus Tri Setyawan ${ }^{2}$, Aryani Witasari ${ }^{3}$ \\ ${ }^{1}$ Doctorate Student of Faculty of Law Sultan Agung Islamic University Semarang, Indonesia \\ ${ }^{2,}$, Faculty of Law Sultan Agung Islamic University Semarang, Indonesia
}

DOI: $10.36348 /$ sijlcj.2021.v04i01.004

| Received: 14.01.2021 | Accepted: 27.01.2021 | Published: 29.01.2021

*Corresponding author: Erwin Riduan

Abstract

The provisions for the formation of a Notary's position as regulated in Law Number 2 of 2014 concerning Notary Office basically need to be used as an additional requirement for the appointment of a Notary, so that it cannot create multiple interpretations between the terms of the appointment of a Notary and the provisions for the formation of a Notary's position. Therefore, it is necessary to make a study that examines the weaknesses of the zoning arrangement for notary positions in Indonesia at this time and how to reconstruct the zoning arrangements for a notary position in Indonesia that is just studied using the socio-legal approach method, namely by conducting reciprocal research between law and nondoctrinal institutions. is empirical/ social in analyzing legal principles that apply in society. The results showed that the arrangement of zoning expansion of notary positions in Indonesia has not been able to solve the problem of equal distribution of notaries. Permenkumham Number 27 of the Year 2016 concerning Formation of Notary Positions and Determination of Regional Categories. The minister's authority to appoint notaries in certain districts/ regions is limited according to the existing formation. Constraints and solutions in the arrangement of zoning for notary positions in Indonesia that the placement of Notaries is in accordance with their designation, due to the fact that the submission of work placements by Notaries is not evenly distributed, many Notaries ask for formations in big cities only, Notaries rarely apply for placements in small cities, To overcome this the Government issued a regulation, namely Decree No. M.01.HT.03.01, of the Year 2003, Concerning Notaries Article 5 in conjunction with Decree No.M.01.HT.03.01, of the Year 2006 concerning Terms and Procedures for the Appointment, Transfer and Dismissal of Notaries. Seeing these problems, the Reconstruction of zoning expansion arrangements for notary positions in Indonesia based on the value of justice is needed. Namely by realizing the distribution and distribution of notaries in every district or city that is good and correct according to the needs of the community.

Keywords: Reconstruction, Notary, Authorization Zone, Justice Value.

Copyright (C) 2021 The Author(s): This is an open-access article distributed under the terms of the Creative Commons Attribution 4.0 International License (CC BY-NC 4.0) which permits unrestricted use, distribution, and reproduction in any medium for non-commercial use provided the original author and source are credited.

\section{INTRODUCTION}

The birth of a Notary Office based on statutory regulations gives meaning to the importance of the position, role, and function of the Notary in the life of the nation and state. Based on the order of legislation in Indonesia, the UUJN and its implementing regulations derive from or obtain at the same time the spirit of its enactment from the 1945 Constitution. basic norms (grundnorm) of state life as well as Article 1 paragraph (3) which states that the Indonesian State is a constitutional state. This implies that a Notary is a position mandated by the 1945 Constitution to jointly develop and achieve the goals of the Indonesian State within the framework of a constitutional state based on Pancasila. It is not an exaggeration to say that the
Notary is essentially holding a noble position. This noble character is reflected when the notary takes an oath and promise before carrying out his position, which in essence is a form of respect for the mandate given by the state.

Notaries are the only public officials appointed by the state (through the authority delegated to the Minister of Law and Human Rights) who do not receive salaries and pensions like other state servants. A Notary has two sides of rights and obligations in himself, in addition to carrying out the rights and obligations as a public official, namely a state representative in civil affairs, physically a Notary is also an ordinary human whose nature is the creation of God almighty who has natural rights and obligations of mankind, including the 
right to live properly, the right to obtain justice and the right to obtain legal protection and to be treated fairly with due observance of the position he holds, therefore both sides must support each other [1].

The fulfillment of the rights and obligations of the notary office depends on the fulfillment of the rights and obligations of the individual Notary as a natural human being created by God. On the other hand, the rights and obligations of individual Notaries as natural human beings created by God through their choice to serve the State by holding the position of Notary are expected to be fulfilled properly and fairly. Both sides should receive equal attention from the state because this determines the uprightness and solidity of the Indonesian Notary's position and of course, affects the honor and dignity of the state as the author of attribution for the notary's position. Notary as a position needs a person appointed to take the office. Outwardly, the holder or holder of a Notary office is an individual citizen who meets the requirements to carry out the mandate of the position. As an individual, a citizen has natural rights that must be respected and upheld by the state, apart from of course individual obligations.

Based on Law Number 30 of 2004 concerning the Position of Public notary (UUJN) as amended by Law Number 2 of 2014 concerning Amendments to Law Number 30 of 2004 concerning the Position of Public notary, in particular Article 18 paragraph (2) states that the working area of a notary covers the entire province from his domicile. This means that the notary is authorized to make deeds as long as the legal action is carried out within its working area, which covers all provinces in the place of domicile of the notary concerned. For example [2], A notary who is domiciled in Bekasi, has the right to make deeds in Bandung, Cirebon, Sukabumi, and so on. Because these areas are still included in their working area (West Java province). However, he is not entitled to make a deed in Tangerang, even if its distance is closer to Bekasi. Because Tangerang is already included in Banten Province.

This problem is what urges the author to study it further in a research with the following issues

1. What are the weaknesses of the zoning arrangement for notary positions in Indonesia currently?

2. How is the reconstruction of the zoning arrangements for notary positions in Indonesia based on justice value?

\section{METHOD OF RESEARCH}

The paradigm that is used in the research this is the paradigm of constructivism which is the antithesis of the understanding that lay observation and objectivity in finding a reality or science knowledge [3]. Paradigm also looked at the science of social as an analysis of systematic against Socially Meaningful
Action through observation directly and in detail to the problem analyzed.

The research type used in writing this paper is a qualitative research. Writing aims to provide a description of a society or a certain group of people or a description of a symptom or between two or more symptoms.

Approach method used in this research is Empirical-Juridical [4], which is based on the norms of law and the theory of the existing legal enforceability of a law viewpoint as interpretation.

As for the source of research used in this study are

1. Primary Data is data obtained from information and information from respondents directly obtained through interviews and literature studies.

2. Secondary Data is an indirect source that is able to provide additional and reinforcement of research data. Sources of secondary data in the form of: Primary Legal Material and Secondary Legal Materials and Tertiary Legal Material.

In this study, the author use data collection techniques, namely literature study, interviews and documentation where the researcher is a key instrument that is the researcher himself who plans, collects, and interprets the data [5]. Qualitative data analysis is the process of searching for, and systematically compiling data obtained from interviews, field notes and documentation by organizing data into categories, describing it into units, synthesizing, compiling into patterns, selecting important names and what will be studied and make conclusions.

\section{RESEARCH RESULT AND DISCUSSION}

1. Weaknesses of the Zoning Arrangement for Notary Positions in Indonesia Currently

The Weaknesses of The Current Zoning Arrangements for Public notary Positions in Indonesia are basically divided into two things, namely due to expansion and the lack of notaries in remote areas. Regional expansion in Indonesia is the establishment of new administrative areas at the provincial and city and district levels from the parent. The most recent legal basis for regional expansion in Indonesia is Law No. $23 / 2014$ on Regional Government. One of them is the division of regions in Indonesia as stated in Law Number 9 of 2003 concerning the Establishment of South Nias Regency, Pakpak Bharat Regency, and Humbang Hasundutan Regency which was issued on February 25, 2003.

After the issuance of this Law, Nias district became 5 Cities / Regencies:

1. North Nias Regency;

2. West Nias Regency;

3. South Nias Regency;

4. Nias Induk Regency; and 


\section{Gunungsitoli Municipality}

From the division of the region in Nias, there are 1 Public notary in South Nias and 4 Public notaries in Gunungsitoli Municipality. This means that 3 Regencies/ Cities in Nias do not have a notary who is domiciled in that area, especially in Parent Nias, North Nias, and West Nias. In practice, many Notaries who are domiciled in the South Nias Region and Gunungsitoli Municipality have committed violations by taking over their duties and positions outside their positions such as Nias Induk, North Nias, and West Nias. This is contrary to Article 19 of the Law on the Position of Public Notary.

Meanwhile, in Dairi Regency [6] that was divided into two districts, namely Dairi Regency as the parent district and Pakpak Bharat Regency. After the division in Dairi Regency, it turned out that there were also many areas where there was no notary position. So that notaries in Pakpak Bharat who have been executed by the expansion still take up their duties and positions in the Pakpak Bharat area. and many more. The same problems often arise in the expansion areas. Like in Sulawesi, Irian, Asahan, and many others. The notary should have known the domicile and area of office at the time the notary's position formation was determined at the time of the notary's appointment,

In the case of the placement of a notary in a region, it must also pay attention to the formation of a notary position, which is regulated in Chapter IV, the second part of Article 21 and Article 22 of Law number 30 of 2004. Based on Article 21 of Law Number 30 of 2004 stipulates that the minister is authorized to determine the formation of notary positions in the regions as referred to in Article 18 paragraph (1) UUJN No. 30 of 2004 in conjunction with UUJN No. 2 of 2014 by considering proposals from notary organizations.

Provisions regarding the formation of this notary office will be further regulated in a ministerial regulation. This is regulated in article 22 of law number 30 of 2004. Within the period of carrying out his position, the notary may change his domicile. Regarding the Notary who will move the domicile of the notary, he must submit a written application to move the notary's office to the minister. This application is filed after obtaining permission from the notary organization and after 3 (three) consecutive years carrying out his / her duties in the region or city where the notary is domiciled. This is regulated in article 23 of Law Number 30 of 2004.

The formation of notary positions as referred to is a guideline for determining regional categories are, namely:

a. Category A, which includes: South Jakarta Administrative City; West Jakarta Administrative
City; Central Jakarta Administrative City; North Jakarta Administrative City; Administrative City of East Jakarta.

b. Category B, which includes: Bandung City; City of Surabaya; Semarang city; Medan city; Makassar city; South Tangerang City; Bekasi city; Yogyakarta City; Depok City; Bogor Regency; Tanggerang Regency; and Sleman Regency.

c. Category C, which includes: Bekasi Regency; Bogor city; Tangerang City; Sidoarjo Regency; Bantul Regency; Surakarta City; Deli Serdang Regency; Gowa Regency; Batam city; Pekanbaru City; Denpasar City; Bandung district; and Gianyar Regency.

d. Category D, which includes regencies/ cities other than Regional Category A, Regional Category B, and Regional Category C.

Regional category A is specifically designated for the movement of the notary's position from regional category B. Regional category B is for the movement of the notary's position from category $\mathrm{A}$ and regional category C. Regional category $\mathrm{C}$ is for the movement of the notary's position area from regional category A, regional category $\mathrm{B}$ and regional category $\mathrm{D}$. area $\mathrm{D}$ for the transfer of the notary office area from all regional categories and the appointment of a notary.

In certain circumstances, the minister can transfer the notary outside the provisions of the category as intended previously based on the notary's request. Regarding requests for notary appointment and transfer of notary office areas that have entered electronically in the waiting list and waiting list reserve prior to the enactment of this ministerial regulation, a formation is given on whether he or she is to be appointed or transferred.

Granting the qualification of a notary as a public official is related to the authority of a notary, according to article 15 paragraph (1) UUJN No. 30 of 2004 in conjunction with UUJNNo. 2 of 2014 that a notary is authorized to make authentic deeds as long as the making of these deeds is not assigned or excluded to other officials or persons. The granting of authority to other officials or agencies, such as the civil registry office, does not imply qualifications as public officials but only performs their functions as public officials when making deeds determined by legal regulations, and their position remains in their original position as civil servants.

In the notary sector, Indonesia is still developing its human resources. So that in practice many people in remote areas do not have authentic certificates due to the lack of equal distribution of notaries, especially in rural areas. This phenomenon in Indonesia is quite ironic. The number of notary graduates in tertiary institutions each year is not comparable to the placement of notaries in remote areas, especially 
underdeveloped areas. This clearly adds to the problems in making authentic deeds.

Tarempa village [7], for example, is one of the villages in Siantan sub-district, Anambas Islands Regency, Riau Province, Indonesia. It is located on the north Coast of Siantan Island. In the Tarempa area, it is one of the remote areas so that notaries in this area cannot be found, apart from Tarempa, there are also other areas such as the Enggano area which is a subdistrict in North Bengkulu Regency, Bengkulu, Indonesia. Enggano is an island located in the southwestern region of Bengkulu province and administratively is the farthest sub-district from North Bengkulu district; therefore this area is so remote and uneven for the notary in Bengkulu because in the Enggano area there is no notary. The unequal distribution of notaries in Indonesia has resulted in many notaries who come from other areas according to their position to receive certificates in remote areas that are outside of their positions and outside their areas of the office. If seen closely, this is a notary violation that violates article 19UUJN No. 30 of 2004 in conjunction with UUJN No. 2 of 2014.

\section{Reconstruction of the Zoning Arrangements for Notary Positions in Indonesia Based On Justice Value}

The legal profession is a noble profession (officium nobile) and is obliged to prioritize the values of morality that have been embedded in every human being to maintain the dignity of the profession [8]. The skills and abilities of the legal profession must be dressed with high morality in practice; otherwise, the nihilism of morality causes the life of the social order of society to be damaged. This can be addressed, of course, if people in the profession have high morality and rely on the norms that apply in society. The function of norms is to provide guidance to humans about how a person should act in society, as well as which actions to carry out and which to avoid.

The position of the notary profession is a profession that carries out the duties of some of the State's powers, especially in the field of private law, besides that it also has an important role in making authentic deeds that have the most perfect evidentiary power. The position of the notary profession is a position of trust; therefore a Notary must have good behavior guaranteed by law, while the law has mandated the association to establish a code of ethics for the Notary profession. A Good Public Notary Behavior is a behavior based on the Notary's professional code of ethics, thus the Notary's professional code of ethics must regulate the things that must be obeyed by a Public Notary, in carrying out his position and also outside his position.

The need for a notary in a regency or city will be adjusted to the formation determined in a regency or city based on a ministerial decree. The minister's authority to appoint notaries in certain regions/ districts is limited according to the existing formation. This is aimed at organizing equitable services to the Indonesian people throughout the archipelago which constitute a unified whole within the unitary state of the Republic of Indonesia.

Formation of the Current Notary Position based on Article 7 Paragraph (2) of regulation of the minister of law and human rights (Permenkumham) No. 27 of 2016 are arranged based on categories A, B, C, and $\mathrm{D}$. Based on the results of interviews with the West Jakarta Ministry of Law and Human Rights regional offices, the system for determining the formation of a notary position is determined based on Article 5 Paragraph (1) Permenkumham Number 27 of the Year 2016 concerning Notary Position Formation and Determination of Regional Categories where Notary position formation is determined based on:

a. business activities;

c. total population; and/ or

d. the average number of deeds drawn up by and/ or before a notary every month.

Determination of business activities in each district/ city based on data from banks where The determination of the population is based on data from government agencies or institutions in charge of the population sector and the determination of the average number of deeds drawn up by and/ or before a notary every month uses a database from the Directorate General of General Legal Administration. If there are not too many deeds made by/ in front of the notary, then there will not be many formations for notary positions. This is one of the reasons for the difference in the number of notary position formations in each district/ city because it must be adjusted to the needs of each region.

Things that need to be considered for notaries who will apply for an appointment or transfer of office areas are:

a. Regional Category, where Notary must pay attention to whether the area being applied for is in the region category A, B, C, or D. For example, prospective notaries are only allowed to apply for an appointment for regional category D. Notaries who come from regional category D cannot apply for transfer the working area to the category B region, but must first apply for a move to the category $\mathrm{C}$ area. Therefore it is very necessary for notaries who wish to apply for appointments or transfers to pay attention to Article 7 paragraph (2) Permenkumham number 27 of 2016 concerning regional categories and to access the website of the Director-General of general law administration (AHU) to find out the formation of available notary positions. 
b. Identity Card (KTP) of Notary needed for applying for appointment or transfer of office area does not have to follow the address listed on the KTP. For example, a Notary whose KTP is located in Cilacap Regency can apply for an appointment or transfer of a position in Magelang Regency as long as it is still in the same area category. On the other hand, with the existence of regulations regarding regional classifications in the form of A, B, C, and D, notaries whose KTP is located in the city of Semarang cannot apply for an appointment in the city of Semarang. Considering that Semarang City is in the category B area, the notary must apply for an appointment in another area that is in the category D area.

c. Requirements for the Appointment and Transfer of Public Notary Apart from the regional category and $\mathrm{KTP}$, the most important thing that must also be prepared by a notary is the requirements for the application for appointment and the requirements for moving the area of the office. This is so that the request from the notary can be processed immediately by the verifier and if the requirements are complete, it is likely that the application for appointment or transfer can be accepted.

The terms and conditions for the appointment of a notary along with the procedure for requesting his appointment have been regulated in Article 3 UUJN and Article 3 Paragraph (1) of Permenkumham Number 25 of 2014 concerning Requirements and Procedures for Appointment, Transfer, Dismissal, and Extension of the Notary's Term of Office. Meanwhile, the requirements for the transfer of a notary and the procedure for filing a transfer application are specified in Article 23 of Law no. 30 of 2004 and Article 30 to Article 32 of Permenkumham Number 25 of 2014 where the duties and functions of the Ministry of Law and Human Rights regarding the formation of notary positions include:

a. Determining the number of notaries needed at a place and used as a guide in carrying out the appointment and transfer of notaries.

b. Appointing a notary at a domicile upon the application concerned.

c. Transferring a notary from one place of domicile to another domicile by taking into account the population, the development of the business world, and a recommendation from the Public notary Organization and the Notary Supervisory Council.

d. Making policies related to the formation of notary positions in the form of regional classifications

e. Pursuant to Article 9 Permenkumham Number 27 Year 2016 in certain circumstances, the minister may transfer notaries outside the category provisions as referred to in Article 8 based on a request from a public notary.

f. Determining the formation of a notary position after receiving consideration from the Notary Organization. g. Determining the formation of notary positions in all regions in Indonesia for a period of 4 (four) years. (Article 3 Paragraph (1) Permenkumham No.27 of 2016)

h. The Minister has the authority to add Notary Position Formations outside those that have been determined.

The Implementation of Article 7 paragraph (1) and (2) of Permenkumham No. 27 of the year 2016 which regulates regional categories, For example, a notary who is domiciled in the Semarang Regency area will have a separate application as well as a notary who is domiciled in the Semarang City area, so that if there are problems such as, the number of deeds issued by the notary, it can be accessed easily and more systematically. Article 4 of Permenkumham No. 27 of the year 2016 states that information regarding the Notary Position Formation must be published on the official website of the Directorate General of General Legal Administration of the Ministry of Law and Human Rights. The Directorate General of General Legal Administration is one of the implementing elements at the Ministry of Law and Human Rights which is tasked with organizing the formulation and implementation of policies in the field of general legal administration services in accordance with the provisions of laws and regulations.

In the implementation of the notary's office in Indonesia, there are still problems that need to be immediately sought for solutions especially related to the formation of notary positions. With the increasing population, increasing economic growth, the expansion of regencies/ cities in Indonesia, as well as increasing public understanding and awareness of legal services provided by Notaries, and in order to expand the spread of legal services by Notaries throughout Indonesia, it is necessary to make arrangements to the Formation for Notary's Position and the Determination of Regional Categories.

Based on the provisions of Article 3 of Law Number 2 of 2014 concerning the Position of Public Notary, the requirements to be appointed as Public Notary do not state that the formation of a Notary's position is a requirement for the appointment of a Notary. However, in practice, there are often several cases of appointment and placement of different working areas for a Public Notary. This will affect the deeds he makes and affects the authenticity of the deeds he makes. And this is what will be very detrimental to society. In addition, in Article 5 Permenkumham Number 25 of the Year 2014 concerning Terms and Procedures for Appointment of Dismissal and Term Extension of Public notary, it is explained that the application for the appointment of a Notary shall take into account the Notary's Position Formation that has been determined by the Minister. However, this provision is not included in the requirements for the appointment of a Notary, even though it has clearly 
stated the steps that can be taken for a person who wishes to apply to be appointed as a Public Notary.

The Ministerial Regulation, in implementing regulation is basically must be firmly based on and sourced from higher legislative regulations where In this case, The Ministerial Regulation Number 25 of 2014 concerning Terms and Procedures for the Appointment, Transfer, Dismissal and Extension of the Office of Public notary is not yet based on the statutory regulations for notary office, namely, Law Number 2 of the year 2014 concerning Amendments to Law Number 30 of 2004 Regarding the Position of Public notary, which in the Law on the Position of Notary is not regulated explicitly and expressly regarding the rules for the appointment of a Public notary which must observe the Notary Position Formation that has been determined by the Minister of Law and Human Rights.

The formation of a Notary's position should have been regulated in the Law on Notary Position. However, in the Law on the Position of Public notary, the provisions for the formation of a Notary's position are regulated in an article that is different from the article that regulates the requirements for the appointment of a Notary. Meanwhile, many prospective Notaries have experienced difficulties when they want to apply for appointment as Public notary and have met the requirements stipulated in Article 3 of the Law on Notary Position.

The provisions for the formation of a Notary's position as stipulated in Article 21 and Article 22 of the Law on Notary Position which is placed in separate with the conditions for the appointment of a Notary as stipulated in Article 3 of the Law on the Position of Public notary can be considered that there are overlapping with the Public notary position law in which, the conditions for the appointment of a Notary can be interpreted as something that must be fulfilled so that the rights of the prospective Public notary, namely the right to be appointed as Public notary can be implemented.

Based on the theory of legal certainty which explains that legal certainty is an enforceable law that is in accordance with the legal substance that has been agreed upon by the community where the law applies. So the provisions for the formation of a Notary's position as regulated in Law Number 2 of 2014 concerning the Position of Public notary are used as additional conditions for the appointment of a Notary, so as not to create multiple interpretations between the terms of the appointment of a Notary and the provisions for the formation of a Notary's position.

Notaries are the only public officials appointed by the state (through the authority delegated to the Minister of Law and Human Rights) who do not receive salaries and pensions like other state servants. A Notary has two sides of rights and obligations in himself, in addition to carrying out the rights and obligations as a public official, namely a state representative in civil affairs, physically an individual Notary is also an ordinary human whose nature is the creation of God who has natural rights and obligations of mankind, including the right to live a decent life, the right to obtain justice and the right to obtain legal protection and to be treated fairly with due observance of the position he holds.

Notary as a position needs a person appointed to take office. Outward-speaking, the holder of a Notary's position is an individual citizen who meets the requirements to carry out the mandate of the position. As an individual, a citizen has natural rights that must be respected and upheld by the state, apart from of course individual obligations. The basic rights of citizens are generally formulated as human rights. The 1945 Constitution (amendment IV) regulates the protection of Human Rights which are considered to be directly related to individual Notary position holders and the nature of the Notary position, consisting of 4 aspects, namely:

a) legal protection aspects;

b) aspects of economic protection;

c) aspects of morality and justice;

d) Aspects of the state's responsibility for the protection, advancement, enforcement, and the fulfillment of human rights.

The four aspects are "das sollen" or "should be", "ideal", "aspire to" to be realized, built and maintained for the position of public notary based on its essence. But in reality (das sein), these four aspects do not work in accordance with the "aspirations". In the practice of notary office, there is a "denial" of the importance of these four aspects being upheld and fought for in order to maintain and uphold the honor and dignity by the the Notary. Among these denials, are [9]:

a. The number or formation of a Notary's position in an area that is considered to exceed the capacity of the region which triggers unfair competition among Notaries;

b. The existence of unfair competition among Notaries such as "tariff wars";

c. There is a phenomenon of "deed fabrication", where a Notary in only one day or one month issues an unreasonable amount of deed when connected to the obligation to "appear before" the parties in accordance with UUJN provisions and the notary's oath of office;

d. The implementation and enforcement of the position code of ethics for a Notary that is not effective and not in accordance with what it should be; 
Seeing the foregoing, the ideal Notary Position Formation System is a system that manages to realize the distribution of notaries in every district or city that is good and correct according to the needs of the community so that people get maximum legal services, especially those in rural districts/ cities. Permenkumham Number 27 of the Year 2016, in its implementation, has not succeeded in realizing the ideal notary position formation. For example, in Jepara district, only a few notary offices exist, which makes the people in need of their services to travel quite far. Meanwhile, in Kendal district, many notary offices have been established which are even very close to each other.

Notaries who are reluctant to have offices in small districts/ cities is one of the reasons for the uneven formation of notaries in Central Java Province In addition to the public knowledge of the role of a notary that is still very minimal. The notary profession is considered a profession that is still foreign to the ears of the community, especially those in rural areas. Therefore, policymakers (ministers) should better understand in translating Ministerial Regulations related to these aspects, namely, economic dynamics, number of deeds, and so on for placement parameters whether they have been observed so that the placement for a Notary is appropriate so that the regulation can run well. Additionally, notaries are expected to provide legal counseling regarding the making of deeds to the public. Community participation is absolutely necessary so that government administrators can get to know their citizens better and their ways of thinking and living habits, the problems they face, suggested ways or solutions, what can be contributed in solving the problems at hand.

Public participation in the formation of laws and regulations is a manifestation of the implementation of the principle of transparency which is one of the principles in the formation of good legislation. In addition, participation from competent parties in their fields is very important so that it becomes a consideration in determining the formation of notaries, for example from Notaries, students of the Faculty of Law Master of Notary, and the public as parties served and recipients of Notary services to be given the opportunity by the Government to participate in contributing ideas. by providing critical, constructive and solution input related to the determination of notary formation, in order to create public services by notaries that are effective, efficient and equitable.

\section{CONCLUSION}

1. The Weaknesses of zoning arrangements for notary positions in Indonesia currently are that they are always oriented to the economic situation and conditions of the placement area (as needed). In the next stage, the Notary usually starts to feel uncomfortable if the economic development of the area where the notary's domicile is not progressing as expected, then they begin to want to move to a place or area with more advanced or stable economic conditions. The distribution of notaries is uneven due to the fact that the application for work placements by notaries is not evenly distributed, many notaries ask for formations in big cities only, notaries rarely apply for placements in small cities, especially because the higher education institutions that manage the Notary Masters (Mkn) mainly exist in big cities, while the Notary Position is a professional profession in the sense of not receiving a salary from the government. To overcome this, the Government, namely the Minister of Law and Human Rights, issued a regulation, namely Decree No. M.01.HT.03.01, of the Year 2003, Concerning Notaries Article 5 in conjunction with Decree No.M.01.HT.03.01, of the Year 2006 concerning Terms and Procedures for the Appointment, Transfer and Dismissal of Notaries. They determined that the formation of Notaries in the Special Region of the capital city of Jakarta, the City of Surabaya, the City of Bandung, the City of Semarang and the City of Medan, is only intended for Transfer Notaries, which is an act committed by a notary wishing to change domicile, stipulated by the Ministry of Law and Human Rights through Decree No.M. .01.HT.03.01, 2006 concerning the Requirements and Procedures for the Appointment, Transfer, and Dismissal of Notaries. The period of time required to move to a new area is the condition that the notary must undergo his notary duties for three years. After that he can move his domicile, the final destination is DKI Jakarta so that the number will increase which causes the unhealthy competition to begin like slashing prices so that it is safe for them to try to work as retainers as there is a tendency for them to dare to break the law using this way.

2. The Reconstruction of the zoning arrangements for a notary office in Indonesia that is just can be realized by realizing good and correct distribution of notaries in each district or city according to the needs of the community so that people get maximum legal services, especially those in remote districts/ cities. Determination of business activities in each district/ city based on data from banks. The determination of the population is based on data from government agencies or institutions in charge of the population sector, while the determination of the average number of deeds drawn up by and/ or before a notary every month uses a database from the Directorate General of General Legal Administration. If there are not too many deeds made by/ in front of the notary, then there will not be many formations for notary positions. This is one of the reasons for the difference in the number of notary position formations in each district/ city because it must be adjusted to the needs of each region. 


\section{REFERENCES}

1. Gunawan, I. K. A., Sumardika, I. N., \& Widiati, I. A. P. (2020). Penetapan Honorarium Notaris dalam Praktik Pelaksanaan Jabatan Notaris. Jurnal Konstruksi Hukum, 1(2), 369-373.

2. Husthinob, D. (2018). Kedudukan Akta Fidusia Yang Dibuat Oleh Notaris Yang Diluar Daerah Jabatannya (Doctoral dissertation, Fakultas Hukum UNISSULA).

3. Faisal. (2010). Menerobos Positivisme Hukum, Rangkang Education, Yogyakarta.

4. Johnny Ibrahim. (2005). Teori dan Metodologi Penelitian Hukum Normatif, Bayumedia, Surabaya.

5. Moleong, L. J. (2004). Metode Penelitian Kualitatif, PT. Remaja Rosdakarya: Bandung.
6. Pogosyan, T., \& Pogosyan, E. (2020). Notarial Services In The Pandemic Setting: Challenges And Opportunities. Notary. 8. 10-12.

7. Negara, H. K., \& Saleh, M. (2018). Kewenangan Pembuatan Akta Bagi Notaris Yang Berada Di Daerah Provinsi Hasil Pemekaran. Transparansi Hukum, 1(2).

8. Widodo, W., Budoyo, S., \& Pratama, T. G. W. (2018). The role of law politics on creating good governance and clean governance for a freecorruption Indonesia in 2030. The Social Sciences, 13(8), 1307-1311.

9. Kostikova, G. (2020). Some Aspects of Performance of Notarial Acts in Territories Having No Notary. Notary. 2. 11-14. 10.18572/1813-1204-2020-2-11-14. 